\title{
Phytochemical screening and evaluation of analgesic and antiinflammatory activities of P hasedus vulgaris linn., seeds in rodents
}

\author{
M. R. Pradeepkumar ${ }^{1,2}$, Shrinivas D. Joshi ${ }^{1 *}$, V. H. Kulkarni ${ }^{3}$, Chetan Savant ${ }^{3}$ \\ ${ }^{1}$ Centre for Research and Development, Prist University, Thanjavur, Tamil Nadu 613 403, India. ${ }^{2}$ Novel Drug Design and Discovery Laboratory, \\ Department of Pharmaceutical Chemistry, S.E.T's College of Pharmacy, S. R. Nagar, Dharwad, Karnataka 580 002, India. ${ }^{3}$ Department of Pharmacology, \\ S.E.T's College of Pharmacy, S. R. Nagar, Dharwad, Karnataka 580 002, India.
}

\begin{tabular}{l} 
ARTICLE INFO \\
\hline Article history: \\
Received on: 07/04/2015 \\
Revised on: $25 / 04 / 2015$ \\
Accepted on: 09/05/2015 \\
Available online: $27 / 06 / 2015$ \\
\hline Key words: \\
Analgesic, \\
Antiinflammatory, Phaseolus \\
vulgaris Linn., seeds, \\
carrageenan, glacial acetic \\
acid. \\
\hline
\end{tabular}

\section{INTRODUCTION}

Inflammation is a body's defense mechanism in response to various infectious or metabolic stimuli. It is a body defence reaction in order to terminate or limit the spread of injurious agent as well as to remove consequent necrosed cells and tissues. Suppression of inflammation still continues to be a challenge to the scientists despite the availability of number of NSAID's. This is because NSAID's not only exhibit antiinflammatory and analgesic activity but also cause gastrointestinal complications ranging from dyspepsia to upper GI tract bleeding and perforation. Efforts to improve adverse effect profile of current NSAID's have been focused on developing pro-drugs or modification of marketed formulations (Schenone et al., 2006).

\footnotetext{
* Corresponding Author

Dr. Shrinivas D. Joshi, Professor \& Head, Dept. of Pharmaceutical Chemistry, S.E.T's College of Pharmacy, S. R. Nagar, Dharwad-580002. Karnataka, India. Mobile: +919986151953.

E-mail: shrinivasdj@ rediffmail.com
}

A recent approach is development of selective cyclooxygenase inhibitors (COX-2). Currently available NSAID's inhibit both COX-1 and COX-2. Inhibition of COX-1 reduces production of cytoprotective prostaglandins PGE2 and PGI2 and hence causes ulceration, while inhibition of $\mathrm{COX}-2$ inhibits inflammation. Complete inhibition of $\mathrm{COX}-1$ is therefore not preferred and drugs that selectively inhibit COX-2 are better antiinflammatory agents. Another field of greater concern is synthesis of more effective analgesic agents. Pain is in fact a very serious problem associated in $90 \%$ of diseases. NSAID'S, which are used to treat pain, have several side effects. There is a great need to develop some natural agents (phytoconstituent), which are capable of treating both acute and chronic pain. Plants have payed a remarkable role in health care since the ancient times. Traditional plant based medicines still exert a great deal of importance to people living in developing countries and also lead to discovery of new drug candidates (Orhan et al., 2007). Phaseolus vulgaris (Linn) seeds belong to the family of Fabaceae (Romero-Arenas et al., 2013). 
It is a sub-erect or twining annual herb, native of central and South America and is now grown extensively through out the warm regions of the world. Vernacular names of the plant Phaseolus vulgaris are in Kannada- Tingalavari, Hindi-Rajma, Gujarati-Fansi, Kashmiri-Fraa'sh bean, Marathi-Pharas bee and Punjabi-Fras bean. Literature survey revealed that Phaseolus vulgaris (Linn) seeds exhibit different biological activities like enhancement of the bifidogenic effect (Queiroz-Monici et al., 2005), antioxidant (Heimler et al., 2005), anticarcinogenic (Hangen et al., 2002), estrogenic (Stephen et al., 2011), antidepressant (Madhu et al., 2014) and antibacterial and antitubercular (Pradeep Kumar et al., 2014) etc.

Phaseolus vulgaris (Linn) seeds have an important place in the folk medicine of the world and in the traditions of many cultures because of their pharmacotherapeutic effects (Mishra et al., 2010). However, Phaseolus vulgaris (Linn) has not been investigated for analgesic and antiinflammatory activities. Hence, this study was carried out to evaluate the potent bioactive constituents for analgesic and antiinflammatory activities in Phaseolus vulgaris (Linn) seeds.

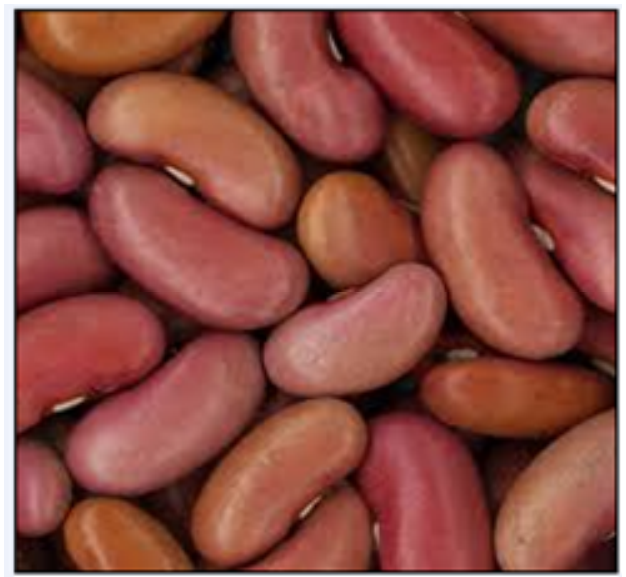

Phaseolus vulgaris Linn seeds

\section{MATERIALS AND METHODS}

The Seeds of Phaseolus vulgaris (Linn) were collected from the local areas of Dharwad in Karnataka and were authenticated by Dr. S. S. Hebbar, Department of Botany, Government Pre-university College Dharwad. A voucher specimen (No- SETCPD/Pharmacog/Herb/2011/12) has been deposited in the Herbarium of Department of Pharmacognosy, S.E.T.'s College of Pharmacy, Dharwad, Karnataka.

The Seeds of Phaseolus vulgaris (Linn) were shade dried and finely powdered to particle size (\#) 40. About $300 \mathrm{~g}$ of dried powder was subjected to continuous hot soxhlet exhaustive extraction with petroleum ether, chloroform and ethanol (95\%). Aqueous extract was also obtained by cold maceration of the drug (300 g) with $2 \%$ chloroform water. After the extraction, the extracts were filtered and concentrated under reduced pressure using a rota evaporator. The yield of petroleum ether, chloroform, ethanol and aqueous extract was found to be $8.36 \mathrm{~g}(3.12 \% \mathrm{w} / \mathrm{w})$,
$6.285 \mathrm{~g}(1.95 \% \mathrm{w} / \mathrm{w}), 24 \mathrm{~g}(7 \% \mathrm{w} / \mathrm{w})$ and $11 \mathrm{~g}(4.01 \% \mathrm{w} / \mathrm{w})$, respectively. All the extracts were kept in a dessicator for drying.

\section{Pharmacological activity}

The pharmacological activities of synthesized compounds were investigated in albino rats and mice. Rats were used for acute anti-inflammatory and chronic anti-inflammatory activities. Mice were used for analgesic activity. All animal experiments were approved by institutional animal ethical committee. All the animals were stabilized to laboratory conditions before starting the experiments.

\section{Acute toxicity}

The acute toxicity test was carried out according to the Organization for Economic Co operation and Development (OECD) guidelines (OECD/ OCDC, 2000) to establish the effective dose of all the synthesized and extracted compounds.

\section{Anti-inflammatory activity}

Anti-inflammatory activity was evaluated using the well known Carageenan induced rat paw oedema model (Winter et al., 1962) using groups of six animals each. A freshly prepared aqueous suspension of carrageenan $(1 \% \mathrm{w} / \mathrm{v}, 0.1 \mathrm{ml})$ was injected in the sub planter region of right hind paw of each rat. One group was kept as control and the animals of the other group were pretreated with the test extract at a dose of $200 \mathrm{mg} / \mathrm{kg}$ body weight of rat, $1 \mathrm{~h}$ before the carageenan treatment. The volume was measured before and after carageenan treatment at the $30 \mathrm{~min}$. interval with the help of digital plethysmometer. Standard drug used was diclofenac at a dose of $200 \mathrm{mg} / \mathrm{kg}$ body weight of rat.

\section{Analgesic activity}

Twenty four hours prior to actual testing a large number of mice (20-25 gm) received intraperitoneally (i.p) $10 \mathrm{ml} / \mathrm{kg}$ of 0.6 $\%$ glacial acetic acid. Animals were observed for writhing movements. Only those showing one or other type of writhing movements (positive responders) were chosen for the test on the next day. On the test day the responders received compounds half an hour prior to glacial acetic acid challenge (Koster et al., 1959). Extracts were given at a dose of $200 \mathrm{mg} / \mathrm{kg}$ orally. Standard drug used was aspirin at a dose of $30 \mathrm{mg} / \mathrm{kg}$ body weight of mice.

\section{RESULTS}

\section{Phytochemical screening}

Phytochemical screening revealed the presence of steroids, flavonoids (Milan, 2011) in the petroleum ether extract of seeds of Phaseolus vulgaris (Linn). The results of the physicochemical parameters and preliminary phytochemical screening of Phaseolus vulgaris Linn seeds is given in Table 1 and Table 2 respectively. Hence, the presence of flavonoids and steroids in petroleum extract could be attributed for observed significant analgesic (Jain et al., 2011; Parveen et al., 2007) and antiinflammatory activities (Sakat et al., 2010; Nagore et al., 
2010). However, research work is under progress to confirm the exact mechanism of action and to elucidate the structure of bioactive principle for the claimed analgesic and antiinflammatory activities.

Table. 1: Physico-chemical parameters of Phaseolus vulgaris Linn seeds.

\begin{tabular}{clc}
\hline Sl.No. & \multicolumn{1}{c}{ Parameter } & $\begin{array}{c}\text { Determined } \\
\text { Value } \% \mathbf{w} / \mathbf{w}\end{array}$ \\
\hline A & Extractive values & \\
1 & Alcohol soluble extractive value & 2.1 \\
2 & Ether soluble extractive value & 0.6 \\
3 & Water soluble extractive value & 6.0 \\
B & Ash Values & \\
1 & Total ash & 8.0 \\
2 & Acid insoluble ash & 1.2 \\
3 & Water soluble ash & 1.7 \\
4 & Sulfated ash & 1.8 \\
C & Moisture content & 2.2 \\
\hline
\end{tabular}

Table 2: Preliminary phytochemical analysis of various extracts of Phaseolus vulgaris Linn seeds.

\begin{tabular}{ccccc}
\hline \multirow{2}{*}{ Phytoconstituents } & \multicolumn{4}{c}{ Successive extraction fractions } \\
\cline { 2 - 5 } & $\begin{array}{c}\text { Petroleum } \\
\text { ether }\end{array}$ & Chloroform & Alcohol & Aqueous \\
\hline Alkaloids & $-\mathrm{ve}$ & $+\mathrm{ve}$ & $+\mathrm{ve}$ & $-\mathrm{ve}$ \\
Steroids & $+\mathrm{ve}$ & $-\mathrm{ve}$ & $-\mathrm{ve}$ & $-\mathrm{ve}$ \\
Carbohydrates & $-\mathrm{ve}$ & $-\mathrm{ve}$ & $-\mathrm{ve}$ & $+\mathrm{ve}$ \\
Phenolic & $-\mathrm{ve}$ & $-\mathrm{ve}$ & $-\mathrm{ve}$ & $+\mathrm{ve}$ \\
Flavonoids & $+\mathrm{ve}$ & $+\mathrm{ve}$ & $-\mathrm{ve}$ & $+\mathrm{ve}$ \\
Glycoside & $-\mathrm{ve}$ & $-\mathrm{ve}$ & $-\mathrm{ve}$ & $+\mathrm{ve}$ \\
Triterpenoid & $-\mathrm{ve}$ & $+\mathrm{ve}$ & $-\mathrm{ve}$ & $-\mathrm{ve}$ \\
Tannins & $+\mathrm{ve}$ & $-\mathrm{ve}$ & $+\mathrm{ve}$ & $+\mathrm{ve}$ \\
\hline
\end{tabular}

+ ve $=$ Present $;-v e=$ Absent

Table 3: Antiinflammatory activity screening of Phaseolus vulgaris Linn seeds.

\begin{tabular}{cccc}
\hline \multirow{2}{*}{ Extract/ Compound } & \multicolumn{3}{c}{ Percentage inhibition of Paw oedema } \\
\cline { 2 - 4 } & $\mathbf{1 h r}$ & $\mathbf{3 h r}$ & $\mathbf{5 h \mathbf { r }}$ \\
\hline Control & - & - & - \\
Aqueous Extract & 22.06 & 31.43 & 26.26 \\
Alcohol Extract & 36.10 & 64.38 & 55.95 \\
Chloroform Extract & 26.20 & $48.53^{*}$ & $42.63^{*}$ \\
Pet-ether Extract & 39.89 & $71.38^{* *}$ & $69.14^{* *}$ \\
Diclofenac & 42.12 & 79.53 & 76.68 \\
\hline
\end{tabular}

Animals were dosed $200 \mathrm{mg} / \mathrm{kg}$. Std. drug diclofenac at a dose of $5 \mathrm{mg} / \mathrm{kg}$ bod weight. Data were analysed by ANOVA. Followed by Dunnet's test. $* * \mathrm{P}<0.001 . \mathrm{P}<0.05$. Values are mean $\pm \mathrm{SEM}$, of six animals in each group.

Table 4: Analgesic activity screening of Phaseolus vulgaris Linn seeds.

\begin{tabular}{llcc}
\hline Extract/ Compound & $\begin{array}{c}\text { No. of wriths } \\
\text { in 15 min. }\end{array}$ & $\mathbf{\pm}$ SEM & \% Protection \\
\hline Control & 44 & 1.713 & -- \\
Aspirin & 13 & 1.317 & 70.45 \\
Aqueous Extract & 32 & 1.163 & 27.28 \\
Alcohol Extract & 24 & 1.392 & $45.46^{*}$ \\
Chloroform Extract & 28 & 1.065 & 36.37 \\
Pet-ether Extract & 16 & 1.447 & $63.64^{* *}$ \\
\hline
\end{tabular}

Animals were dosed $200 \mathrm{mg} / \mathrm{kg}$. Standard drug aspirin at $30 \mathrm{mg} / \mathrm{kg}$ body weight. Data were analysed by ANOVA. Followed by Dunnet's test.

$* * \mathrm{P}<0.001$. $\mathrm{P}<0.05$. Values are mean $\pm \mathrm{SEM}$, of six animals in each group.

\section{CONCLUSION}

The present study provides an evidence for the analgesic and antiinflammatory activities of Phaseolus vulgaris (Linn) seeds. Aspirin used as standard drug for screening the analgesic activity which act by obtunding of peripheral pain receptors and prevention of PG- mediated sensitization of nerve endings (Tripathi, 2013) and the diclofenac which is used as standard drug for screening the antiinflammatory activity that acts by inhibiting the prostaglandin synthesis and specially it is COX-2 selective (Tripathi, 2013). As the activity results (petroleum ether extract) are closer to those of diclofenac and aspirin, the bioactive principles present in the extract may be having the mechanism of action similar to that of the tested standard drugs. However research is under progress to confirm the exact mechanism of action and to elucidate the structure of bioactive principles for the claimed analgesic and antiinflammatory activities. The present study may form the basis for the selection of plant species for further investigation in potent bioactive compounds for analgesic and antiinflammatory activities.

\section{ACKNOWLEDGEMENT}

The authors are thankful to Shri. H. V. Dambal, President, Dr. T. M. Aminabhavi, Research Director, S. E. T's College of Pharmacy for providing the facilities to carry out this research work. The authors are grateful to Mr. Ravi Nadiger and Mr. Vijaybhaskar Joshi for their technical assistance.

\section{CONFLICT OF INTEREST}

Conflict of interest declared none.

\section{REFERENCES}

Hangen L, Bennink M. Consumption of Black Beans and Navy Beans ( $P$. vulgaris) reduced azoxymethane-induced colon cancer in rats. Nutrition and Cancer, 2002, 44 (1): 60-65.

Heimler D, Vignolini P, Dini M, Romani A. Rapid tests to assess the antioxidant activity of Phaseolus vulgaris L. dry beans. J Agric Food Chem, 2005, 53: 3053-3056.

Jain PK, Soni P , Upmanyu N and Shivhare Y. Evaluation of analgesic activity of Manilkara zapota (Leaves), Eur J Exp Biol. 2011, 1 (1); 14-17.

Koster R, Anderson M, De Beer EJ. Acetic acid for analgesic screening. Fed Proc Fed Am Soc Exp Biol. 1959, 18: 412-416.

Madhu D, Ramica S. Antidepressant activity of aqueous extract of Phaseolus vulgaris (black bean) in rodent models of depression, Int J Nutri Pharmacol Neurolog Dis. 2014, 4(2): 118-124.

Milan S. T. Total Phenolic content, flavonoid concentration and antioxidant activity of Marrubium peregrinum L. extracts. Krogujevak J Sci. 2011, 33: 63-72.

Mishra SB, Rao CV, Ojha S. K, Vijayakumar M, Verma A. An analytical review of plants for anti diabetic activity with their phytoconstituent \& mechanism of action: a review. Int J Pharmacol Sci Res, 2010, 1(1): 29-44.

Nagore DH, Ghosh VK, Patil MJ, Wahile AM. In vitro antioxidant and In vivo anti-inflammatory activity of Cassia sophera Linn. Int J Pham Pharm Sci, 2010, 2(1); 114-121.

OECD/OCDC, OECD "Guidelines for Testing of Chemicals", Revised Draft. Guidelines 423; Acute Oral Toxicity Class Method, Revised Document, October 2000.

Orhan I, Kupeli E, Sener B and Yesilada E. Appraisal of antiinflammatory potential of the clubmoss, Lycopodium clavatum L. J Ethnopharmacol, 2007, 109 (1), 146-150.

Parveen Z, Deng Y, Saeed MK, Dai R, Ahamad W and Yu Hong $\mathrm{Yu}$. Analgesic and anti- inflammatory activities of Thesium chinensis extracts and major flavonoids, Kaempherol and Kaempherol-3Glucoside.Yakugaku Zasshi, 2007, 127(8); 1275-1279. 
Pradeep Kumar MR, Joshi SD, Kulkarni VH. Evaluation of antibacterial and antitubercular activity of Phaseolus vulgaris Linn., seeds. International Journal of Pharma and Bio Sciences. 2014, 5 (3); 219- 224.

Queiroz-Monici K, Costa G, Da SN, Reis S, De OA. Bifidogenic effect of dietary fiber and resistant starch from leguminous on the intestinal microbiota of rats. Nutrition, 2005, 21: 602-609.

Romero-Arenas O, Damian Huato MA, Rivera Tapia JA, Baez Simon A, Huerta Lara M and Cabrera Huerta E. The nutritional value of Beans (Phaseolus vulgaris L.) and its importance for feeding of rural communities in Pueblo-Mexico. Int Res J Biol Sci. 2013, 2(8): 59-65.

Sakat SS, Juvekar AR and Gambhire MN. Invitro antioxidant and antiinflammatory activity of methanol extract of Oxalis corniculata Linn. Int J Pham Pharm Sci, 2010, 2(1); 146-155.

Schenone S, Brullo C, Bruno O, Bondavalli F, Ranise A, Filippelli W, Falcone G. New 1,3,4-thiadiazole derivatives endowed with analgesic and anti-inflammatory activities. Bioorg Med Chem, 2006, 14: 1698-1705.

Stephen MB, Matthew EB, Thomas EW, Betty YS, Steven E, Carol H. Estrogenic and antiestrogenic activities of phytolexins from rea kidney bean (Phaseolus vulgaris L.). J. Agric. Food Chem. 2011, 59(1): 112-120.
Tripathi KD. 2013. Essentials of medical pharmacology, $7^{\text {th }}$ edition, Jaypee brothers medical publishers (P) Ltd, 195.

Tripathi KD. 2013. Essentials of medical pharmacology, $7^{\text {th }}$ edition, Jaypee brothers medical publishers (P) Ltd, 204.

Winter CA, Risley EA, Nuss GN. Carrageenan-induced edema in hind paw of the rat as an assay for antiinflammatory drugs. Proc Soc Exp Biol, 1962, 111: 544-547.

\section{How to cite this article:}

M. R. Pradeepkumar, Shrinivas D. Joshi, V. H. Kulkarni, Chetan Savant., Phytochemical screening and evaluation of analgesic and antiinflammatory activities of Phaseolus vulgaris linn., seeds in rodents. J App Pharm Sci, 2015; 5 (06): 066-069. 